\title{
Study of the bone tissue structural-functional state in children in the East of Ukraine
}

\author{
Tatiana Frolova*, Olga Okhapkina, Irina Tereshchenkova, Iryna Siniaieva \\ From 21st European Pediatric Rheumatology (PReS) Congress \\ Belgrade, Serbia. 17-21 September 2014
}

\section{Introduction}

The problem of osteopenia and osteoporosis in children turned from a rare pediatric problem to a frequent pathology which is difficult to diagnose. This problem is especially urgent for the present-day in Ukraine because the level and quality of therapeutic and diagnostic care as well as nutrition quality are influenced by the transformation of the society. The critical years for building bone mass are during childhood and adolescence. This is when a new bone is formed more quickly than the old bone is removed, causing bones to become larger and denser.

\section{Objectives}

The 1126 children aged 9-17 residing in the East of Ukraine.

\section{Methods}

The ultrasound densitometry.

\section{Results}

According to the findings of population study we worked out special nomograms for evaluation of structuralfunctional state of the bone tissue in children population in Ukraine for the use by medical practitioners. Active accumulation of the bone mass is observed between the age of $11-12$, its increase equals $7-8 \%$ per year. The periods of intensive growth and active bone mass accumulation occur at the same time. The incidence of osteopenic disorders in the bone tissue structural-functional state in children aged 9-16 in a large industrial area is $(20.5 \pm 1.1) \%$ and changes with the age, gender, residence from $(14.6 \pm 2.3) \%$ to $(30.3 \pm 4.0) \%$. In the children, the incidence of stage 1 osteopenia is $(9.3 \pm 1.1) \%$, stage 2 $(7.1 \pm 0.8) \%$, stage $3-(4.1 \pm 0.5) \%$. Thus, the most frequent variant of osteopenia is stage 1 disturbance (43.3\% of the cases). $20.0 \%$ of cases are marked osteopenic disorders (stage 3). Age- and gender-related differences in the values of osteopenia prevalence in children are characterized by prevail of its frequency in the young group (9-12 years) over the older group, which is more pronounced in girls $((24.8 \pm 1.8) \%$ and $(18.2 \pm 2.0) \%$, respectively, $\mathrm{p}<0.05)$, first of all due to the larger frequency of stage 3 osteopenia $((6.4 \pm 1.2) \%$ and $(3.5 \pm 0.8) \%$, respectively, $\mathrm{p}<0.05)$. In girls from rural regions, osteopenia incidence was $(16.7 \pm 1.9) \%$. In the younger age group, stage 1 and stage 3 osteopenia were more prevalent $(9.4 \pm 3.3) \%$ and $(6.4 \pm 1.7) \%$, whereas in the older age group the correlation between the prevalence of these variants is smaller. In urban girls osteopenia prevalence was $(26.1 \pm 2.5) \%$, in the younger group, stage 1 osteopenia was more prevalent $(12.1 \pm 3.8) \%$ and stage 3 osteopenia was less prevalent $(2.1 \pm 1.7) \%$, while in the older group correlation of these variant of osteopenia is smaller. In rural boys, the prevalence of osteopenia was $(15.7 \pm 2.1) \%$. In the younger age group, the lowest incidence and, respectively, stage 3 incidence $(2.8 \pm 1.1) \%$ were noted. In children aged 9-12, osteopenia prevalence was $(18.0 \pm 2.2) \% ; 51.1 \%$ of cases were stage 2-3 disease. In children aged 13-16, stage 2-3 osteopenia made $54.8 \%$. Osteopenia prevalence in urban children was revealed to be $(24.3 \pm 2.7) \%$. In children aged 9-12 this made $(27.3 \pm 2.8) \%, 83.6 \%$ of cases being stage 12 osteopenia. The number of stage 1-2 cases reached $85.6 \%$ in the children aged 13-16, which suggests accumulation of osteopenic disorders in the teen-agers.

\section{Conclusion}

The necessity of implementation of nomograms for evaluation of the bone tissue structural-functional state in children in regions with different ecological and medical and social characteristics was proved. 


\section{Disclosure of interest}

None declared.

Published: 17 September 2014

doi:10.1186/1546-0096-12-S1-P299

Cite this article as: Frolova et al: Study of the bone tissue structural-

functional state in children in the East of Ukraine. Pediatric Rheumatology 2014 12(Suppl 1):P299.

Submit your next manuscript to BioMed Central and take full advantage of:

- Convenient online submission

- Thorough peer review

- No space constraints or color figure charges

- Immediate publication on acceptance

- Inclusion in PubMed, CAS, Scopus and Google Scholar

- Research which is freely available for redistribution 